\title{
A Regional Comparison of Stumpage Values in British Columbia and the United States Pacific Northwest
}

\author{
by \\ David Haley ${ }^{1}$
}

\begin{abstract}
In this paper, stumpages in British Columbia are compared with those in the Pacific Northwest region of the United States where public timber is sold in highly competitive markets. In 1978, the average stumpage for public timber in the Pacific Northwest was $\$ 39.11 / \mathrm{m}^{3}$ compared to $\$ 4.58 / \mathrm{m}^{3}$ in British Columbia. Between 1963 and 1978, real stumpage prices in the Pacific Northwest (i.e. net of inflationary increases) showed an upward trend of almos $11 \%$ per annum compared to a slight downward trend for British Columbia. Although the appraisal method used by the United States Forest Service is similar to the method used in British Columbia, appraised stumpages for the British Columbia Coast are considerably lower than for western Washington.

There is little doubt that the principle reason for higher stumpages in the Pacific Northwest is that all public agencies involved in timber production encourage competitive bidding for standing timber, whereas in British Columbia competitive sales of public timber have been virtually eliminated. Other reasons include tax considerations on the part of firms in the Pacific Northwest with private timber holdings, the higher average quality of the timber resource in the Pacific Northwest compared to British Columbia and the fact that forest products companies in the Pacific Northwest face better market opportunities, particularly with respect to plywood, than their counterparts in British Columbia. Imperfections in the Vancouver Log Market may partially explain why appraised timber values in western Washington are higher than on the British Columbia Coast.

There is good reason to believe that if public timber in British Columbia was sold competitively, stumpages, in many cases, would be bid well above their appraised level and direct Crown revenues would be substantially increased, particularly in those regions of the Province where accessible, high quality stands of timber are in short supply.
\end{abstract}

\section{Résumé}

L'auteur compare dans cet article les droits de coupe en Colombie Britannique à ceux en vigueur aux États-Unis dans la région Nord-ouest du Pacifique où le bois est vendu au public sur des marchés fortement compétitifs. En 1978, les droits de coupe moyens pour le bois ainsi vendu se chiffraient, pour la région du Pacifique à $\$ 39.11 / \mathrm{m}^{3}$ contre $\$ 4.58 / \mathrm{m}^{3}$ en Colombie Britannique. Entre 1963 et 1978, les prix réels des droits de coupe sur la côte du Pacifique (i.e. excluant la montée inflationniste) montre une tendance à la hausse de presque $11 \%$ per annum comparativement à ce qui se passe en Colombie Britannique où la tendance était faiblement à la baisse.

Bien que la méthode d'évaluation retenue par le service forestier américain soit semblable à celle utilisée en Colombie Britannique, l'évaluation des droits de coupe pour la côte de la Colombie Britannique s'avère fortement plus basse que celle encourue dans l'état de Washington. Sans doute, la principale raison pour laquelle les droits de coupe sont plus élevés sur la côte ouest du Pacifique, aux États-Unis, réside dans le fait que toutes les agences publiques im. pliquées dans la production du bois encouragent la vente aux enchères pour le bois sur pied, alors qu'en Colombie Britannique ce genre de vente pour le bois debout a été complètement aboli. D'autres raisons comprennent également le point de vue des taxes qui reviennent aux compagnies installées dans la région NordOuest de la côte du Pacifique avec des concessions forestières privées; la qualité moyenne supérieure du matériel ligneux de cette régión comparée à celle rencontrée en Colombie Britannique; et le fait que les compagnies des produits forestiers rencontrent de meilleures facilités de marché, spécialement à ce qui a trait au con-

1. Associate Professor, Faculty of Forestry, University of British Columbia, Vancouver, B.C. treplaqué que celles prévalent en Colombie Britannique. Certains manques dans le marché des bois de Vancouver peut en partie expliquer la raison selon laquelle les valeurs estimées du bois dans l'état de Washington sont supérieures à celles de la côte de la Colombie Britannique.

II ya a tout lieu de croire que, si en Colombie Britannique le bois était vendu de façon compétitive, les droits de coupe, dans bien des cas dépasseraient facilement leur niveau d'estimation de sorte que les revenus de la Couronne augmenteraient sensiblement tout particulièrement dans les régions de la province où les peuplements accessibles et d'excellente qualité ne sont pas très nombreux.

\section{Introduction}

Stumpage is the price paid to the owner of forest land for the right to harvest standing timber. To land owners it constitutes the return for timber produced while logging operators regard stumpage as a cost.

The maximum amount a purchaser can afford to pay for standing timber is the value of the products which can be recovered from it, less the total costs, including a normal profit, of realizing those values. This residual value is the "economic rent"' associated with the timber resource (Reed \& Associates, 1975). In a competitive market for standing timber, the successful bidder will tend to be the most efficient operator, that is, the operator who can realize the highest net return from timber harvesting and processing. Competitive sales will, therefore, ensure that forest land owners obtain the highest possible prices for their standing timber and that stumpage paid is equivalent to the full amount of the economic rent attributable to the timber resource.

In British Columbia, where almost $95 \%$ of the forest land is Provincially owned, competitive sales of public timber are rare as a result of explicit government policies designed to delegate responsibilities for the management of public forest land to the private sector and, by protecting "established operators" from the vaguaries of the marketplace, encourage greater capital investment in the forest industry (Pearse, 1976). In the absence of competitive markets, most public timber is sold at prices determined by the British Columbia Forest Service by means of an elaborate stumpage appraisal system. This system was described in detail by the Task Force on Crown Timber Disposal (1974). While some modifications have been made to the appraisal system since the Task Force reported, it remains essentially the same.

It is a matter of some public concern in British Columbia as to whether appraised stumpages truly reflect the full value of the Province's timber resource. That is, do appraised stumpages approximate the timber values which would result from the operation of freely competitive market forces for the resource? This is more than just an academic question. In the absence competition for most timber sales, the stumpage appraisal system determines the direct revenue the Province obtains from Crown timber resources and the cost to the Province's largest and most important industry of most of its raw material supplies.

\footnotetext{
2. For purposes of this study the Pacific Northwest includes the states of Washington and Oregon.
} 
The extent to which British Columbia's stumpage appraisal system does provide reliable estimates of the full market value of the timber resource might be investigated by comparing competitively determined market prices with appraised prices. On those occasions when competitive sales for standing timber do take place in British Columbia, prices are generally bid well above appraised values. Such sales are infrequent, however, and generally are for small, a typical parcels of timber.

An alternative to comparing competitive and noncompetitive determined timber values within the Province is to compare stumpages in British Columbia with those in the Pacific Northwest region of the United States ${ }^{2}$ where there is a considerable public timber resource which is sold in highly competitive markets. While such regional comparisons must be interpreted with caution, some interesting and useful insights into the pricing of Crown timber in British Columbia can be gained from such a study.

In this paper, stumpage prices in British Columbia and the United States Pacific Northwest are first compared in a general manner. This is followed by a more detailed comparison of stumpage appraisals and timber values for the Mt. Baker/Snoqualmie National Forest in Washington State and the Quadra Public Sustained Unit (P.S.Y.U.) in southwestern British Columbia.

\section{Regional Perspective}

British Columbia has a total area of 95 million hectares compared to 42 million hectares in Washington and Oregon. In each region more than half the total area is classified as forest land: $55 \%$ in British Columbia and $51 \%$ in Washington and Oregon. The quality of the timber resource in Washington and Oregon is, on average, higher than British Columbia. Not only do the forests of the Pacific Northwest produce a higher quality mix of log grades but the timber inventory contains a much greater proportion of higher valued species. For example, $48 \%$ of the timber inventory in the Pacific Northwest is Douglas-fir (Pseudotsuga menziesii (Mirb.) Franco) compared to $7 \%$ in British Columbia (C.O.F.I., 1973).

While both Washington and Oregon have some extremely rugged areas, on the whole the terrain in British Columbia, particularly on the Coast, presents more logging difficulties. The social infrastructure is less developed in British Columbia than in the Pacific Northwest and the British Columbia logging industry operates operates in more remote locations which present major logistical problems.

Forest land ownership differs markedly between British Columbia and the Pacific Northwest. In British Columbia, $95 \%$ of the forest land is publically owned (94\% Provincial and $1 \%$ Federal) and only $5 \%$ is in private ownership. In contrast, $42 \%$ of the forest land in Washington and Oregon is privately owned, $51 \%$ is under Federal jurisdiction, $6 \%$ is under State jurisdiction and $1 \%$ is controlled by local county and municipal governments.

The allowable annual cut for public forest lands in British Columbia in 1977 was 84 million cubic meters compared to 36 million cubic meters for public forest lands in Washington and Oregon 3 . The allowable annual cut in the Pacific Northwest has been almost constant for a number of years and has risen by only four million cubic meters, or about $13 \%$, since 1963. In certain areas, for example National Forest lands in Washington state, allowable annual cuts have declined considerably in recent years.

3. The units of wood measurement used in the Pacific Northwest and those used in British Columbia are entirely different. In the Pacific Northwest the Scribner Decimal C. Board Foot Rule is the most commonly used log scale while in British Columbia the only official scale is the B.C. Firmwood Cubic Rule. The conversion factor from Scribner Decimal $\mathrm{C}$ to B.C. Firmwed is a fubtion In this paper an avera thous paper an thousand board feet; or 1 cubic ft. = approx. 5.4 board feet). All volumes have been converted to cubic metres.
In British Columbia, the allowable annual cut for public forest lands in 1977 was more than three times the 25 million cubic meters reported for 1963 . This increase can largely be attributed to the expansion of forestry operations in the Interior and northern regions of the Province and the adoption and enforcement, in the mid-1960's, of much closer recovery standards (Pearse, 1976). However, with increasing pressures on forest land for non-timber uses and increasing recognition that many stands, currently included in the allowable cut calculation, are sub-marginal, it is unlikely that allowable annual cuts will increase significantly in the future. In fact, in some areas reductions in allowable cuts appear imminent (Province of British Columbia, 1980).

\section{Comparison of Average Stumpage Prices}

In 1978, the average stumpage price paid by the forest industry for public timber in Washington and Oregon was $\$ 39.11$ per cubic meter compared to $\$ 4.58$ per cubic meter in British Columbia 4 . In the Pacific Northwest, average stumpage prices ranged from $\$ 18.60$ per cubic metre for United States National Forests in Eastern Washington to $\$ 50.76$ per cubic metre for Washington State lands in Western Washington. In British Columbia, average stumpage prices for 1978 ranged between $\$ 5.14$ per cubic metre in the Kamloops Forest Region to $\$ 2.37$ per cubic metre in the Interior section of the Prince Rupert Forest Region.

Between 1963 and 1978 average stumpage prices for public timber in the Pacific Northwest increased at a considerably greater rate than in British Columbia (Fig. 1). In real terms (i.e. net of inflationary price increases) stumpage prices in Washington and Oregon showed an average upward trend during this period of almost $11 \%$ per annum compared to a slight downward trend for British Columbia (Figs. 2a and 2b). In British Columbia, therefore, in spite of increasing demands on the timber resource, the real cost of standing timber to the forest industry did not increase between 1963 and 1978. In the Vancouver Forest Region where industrial demands on the timber resource have been more intense than in most other regions of the Province, the real price of standing timber fell at an average rate of almost $2 \%$ per annum between 1963 and 1978 .

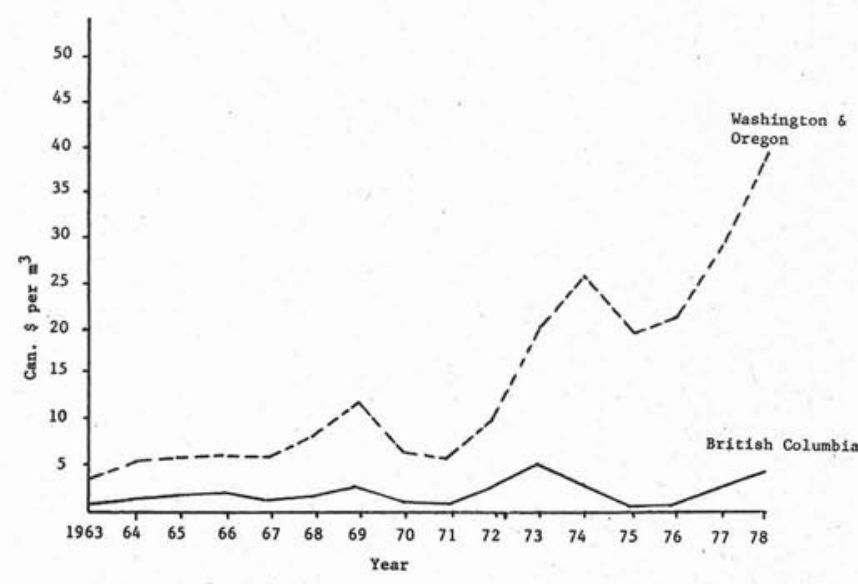

Fig. 1. Average stumpage prices for timber sold on publicly owned lands in Washington and Oregon and Crown lands in British Columbia 1963-78.

Sources: B.C. Forest Service, Annual Reports 1963-78 USDA Forest Service, Production, Prices, Employment and Trade in Northwest Forest Industries 1963-79 (published quarterly)

\footnotetext{
4. Unless otherwise stated, all revenues, costs and prices quoted in this paper are in Canadian dollars.
} 
Comparison of Stumpage Appraisals and

Stumpage Prices for Mt. Baker/Snoqualmie National Forest and the Quadra Public Sustained Yield Unit

In order to examine the factors affecting stumpage prices in British Columbia and the Pacific Northwest in more depth, a detailed comparison was made between sales of public timber during 1977 on the Quadra Public Sustained Yield Unit (P.S.Y.U.) in the Vancouver Forest Region and the Mt. Baker/Snoqualmie National Forest in Washington State. A comparison of stumpage appraisal components, appraised stumpage prices and realized stumpage prices for Douglasfir on these two units is presented in Table 1. An attempt has been made to standardize the presentation of appraisal procedures in the two jurisdictions for comparative purposes, but some differences inevitably persist.

Average logging costs in the Mt. Baker/Snoqualmie National Forest were $11 \%$ higher in 1977 than in the Quadra P.S.Y.U. However, the relative importance of certain cost components differed considerably between the two areas.

Selling prices used for appraisal purposes on the British Columbia coast are based on the prices of logs sold on the Vancouver Log Market, whereas in the United States, Pacific Northwest selling prices are based on the market value of lumber, veneer and pulp chips. In the United States,

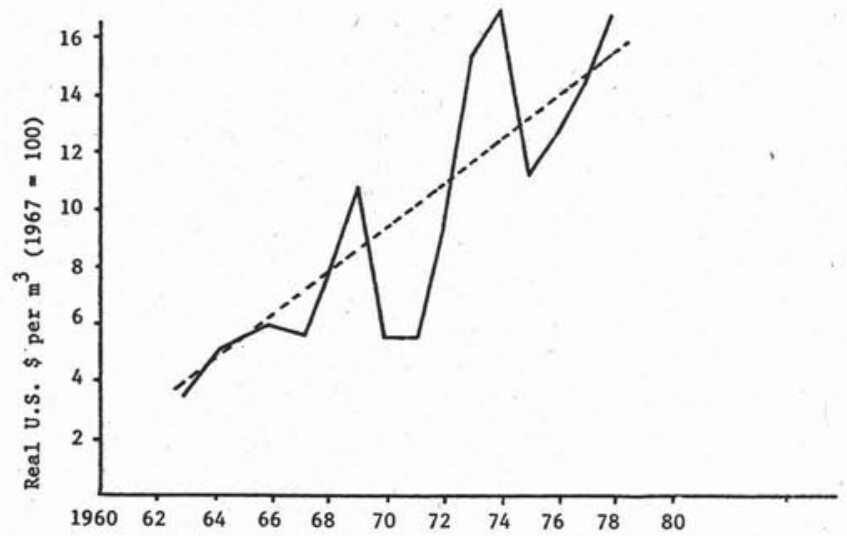

Fig. 2a. Average stumpage prices in real dollars for timber sold on publicly managed lands in Washington and Oregon : 1963-78. therefore, it is necessary to make an allowance for manufacturing costs in the appraisal. Log values can be estimated by subtracting manufacturing costs from endproduct values. The imputed Douglas-fir log value for the Mt. Baker/Snoqualmie National Forest in 1977 was $\$ 59.03$ per cubic metre which was more than double the $\$ 28.82$ per cubic metre for the Quadra P.S.Y.U.

In the Rothery method of stumpage appraisal used in both British Columbia and the Pacific Northwest, the operator's profit and risk allowance is directly related to the selling price used for appraisal purposes. Thus, while the average profit ratio for Douglas-fir in the Mt. Baker/Snoqualmie National Forest $(15.7 \%)$ was lower than in the Quadra P.S.Y.U. $(16.9 \%)$, the profit and risk allowance in the former area was considerably higher. Of course, this higher profit margin included an entrepreneurial return to manufacturing in addition to logging activities.

The average appraised stumpage price for Douglas-fir in the Quadra P.S.Y.U. was only $\$ 0.17$ per cubic metre and the advertised, or upset, price (statutory minimum) was $\$ 2.72$ per cubic metre. On the Mt. Baker/Snoqualmie National Forest, the appraised stumpage price was $\$ 18.96$ per cubic metre and the advertised price (appraised price plus "specified road" costs) was $\$ 27.43$ per cubic metre. The average selling price, following competitive bidding on the Mt. Baker/Snoqualmie National Forest was $\$ 59.22$ per cubic metre: $116 \%$ more than the advertised price.

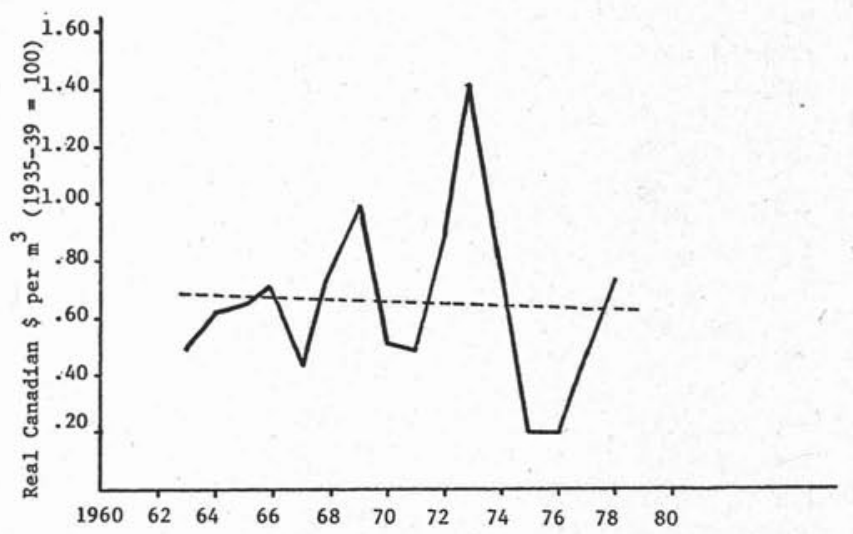

Fig. 2b. Average stumpage prices in real dollars for timber sold on Crown lands in British Columbia - 1963-78. Table 1. Comparison of stumpage appraisal components and appraised and realized stumpage prices for Douglas-fir on the
Quadra Public Sustained Yield Unit (British Columbia) and Mt. Baker/Snoqualmie National Forest (Washington State).

Item

Quadra P.S.Y.U.

Mt. Baker/Snoqualmie

(Can. \$/m) National Forest

1. Selling price:

28.82

(Can. \$/m³)

Logging costs:

Stump to truck

Transportation

Overhead and Depreciation

Environmental Protection

System (Specified) Roads

Forestry Costs

Other Costs

2. Total logging costs

3. Manufacturing costs

4. Conversion Return (1-2-3)

5. Profit and Risk

6. Appraised (Indicated) stumpage (4-5)

7. Advertised (Upset) stumpage

8. Bid stumpage

6.99

5.86

5.22

0.13

3.06

0.09

3.07

24.42

$\overline{4.40}$

4.23

0.17

$2.72^{1}$
95.11

\subsection{7}

4.81

3.01

3.17

8.47

-

27.13

36.08

31.90

12.94

18.96

$27.43^{2}$

59.22

1. Statutory minimum stumpage rate.

2. Indicated stumpage plus specified roads cost. 


\section{Discussion}

There are a number of possible reasons why stumpage prices in Washington and Oregon are considerably higher than in British Columbia. These include differences in: the institutional arrangement for the disposal of public timber; contractual conditions of sale; the supply and demand for timber in the two regions; logging, transportation and manufacturing costs; timber quality and market opportunities.

Clearly, the highly competitive nature of public timber sales in the United States, combined with the fact that in the Pacific Northwest the available supply of private timber is declining and the supply of public timber is heavily constrained on an annual basis (Haynes and Adams, 1979) results in stumpages frequently being bid well above their appraised level. In British Columbia, the market mechanism simply does not exist for translating rising demands for stumpage, or stumpage shortages, into higher prices and most timber is sold at the appraised, or upset, price.

It is frequently suggested that private timber owners in the Pacific Northwest, who can elect to have income derived from timber harvesting treated as capital gains for taxation purposes, have a vested interest in high market values for standing timber and, therefore, bid stumpages for public timber above the level they would otherwise attain. Stumpages, as determined in the marketplace, are used to calculate the income attributable to timber harvesting and are also regarded as the cost of timber inputs for determining subsequent incomes or losses from timber processing. Therefore, the higher the market value for standing timber the greater will be that proportion of an integrated forest product company's total income which is regarded as capital gain. While it is likely that such tax considerations will influence the bidding strategies of certain firms, it is difficult to determine the extent to which they affect average bid stumpages for public timber. Many successful bidders for public timber are firms which do not have private timber holdings.

Not only are selling prices for public timber higher in the Pacific Northwest than in British Columbia, but appraised stumpages for United States National Forests are also considerably higher, although the appraisal system used in both regions is similar in many respects. Higher appraised prices might result from lower costs, smaller allowances for profit and risk or higher product values.

In 1977, appraised logging costs for the Mt. Baker/Snoqualmie National Forest were $11 \%$ higher than in the Quadra P.S.Y.U. The Council of Forest Industries have also found logging costs on the British Columbia Coast and in the Interior to be lower than for comparable regions in the Pacific Northwest (C.O.F.I., 1973). Manufacturing costs are not required for British Columbia coastal appraisals. However, manufacturing costs used in United States Forest Service appraisals in the Pacific Northwest do not seem to be disimilar to manufacturing costs experienced in British Columbia. The Council of Forest Industries (C.O.F.I., 1973) found appraised manufacturing costs in the southern British Columbia Interior to be considerably lower than those used by the United States Forest Service for stumpage appraisals in eastern Washington. The Department of Industry, Trade and Commerce (1977) in a study of North American forest products' manufacturing costs also showed lumber manufacturing costs in the British Columbia Interior to be considerably lower than in the Pacific Northwest while lumber manufacturing costs on the British Columbia Coast were slightly higher. Higher logging and manufacturing costs in the Pacific Northwest, other things being equal, would result in lower appraised stumpage prices for that region than for British Columbia.

Profit ratios used in stumpage appraisals by the United States Forest Service in the Pacific Northwest are of a similar magnitude to those used in British Columbia. The method of calculating the margin for profit and risk is identical in both regions.

It appears, therefore, that differences in appraised stumpages between British Columbia and the Pacific Northwest are mainly due to differences in the selling prices used for appraisal purposes in the two regions. Sales realizations for forest products are dependent on a number of factors including the quality of the wood supply, the mix of products produced and sold, the markets in which the products are sold, the costs of transportation to markets, tariffs and foreign exchange rates.

The quality of the wood supply is indisputably higher in Washington and Oregon than in British Columbia (C.O.F.I., 1973). It is difficult to accurately compare timber quality and assess its impact on appraised stumpages since official grading rules differ considerably between the two jurisdictions. Nevertheless, an attempt has been made to compare the quality of Douglas-fir on timber sales in the Quadra P.S.Y.U. and the Mt. Baker/Snoqualmie National Forest in 1977 (Table 2). Neither area provided a high proportion of first quality logs (No. 1 \& No. 2 Peelers and No. 1 Sawlogs). However, Mt. Baker/Snoqualmie National Forest had a much higher proportion of intermediate grades (low grade Peelers and No. 2 Sawlogs) than Quadra P.S.Y.U. Sixty-four percent of the volume of Douglas-fir appraised in the Quadra P.S.Y.U. was concentrated in No. 3 Sawlogs and lower compared to $19 \%$ for the Mt. Baker/Snoqualmie National Forest.

The impact of lower timber quality on appraised stumpages in the Quadra P.S.Y.U. can be estimated by assuming that the Douglas-fir appraised in 1977 had a grade distribution, by volume, identical to that experienced on the Mt. Baker/Snoqualmie National Forest. By applying Vancouver Log Market prices to the revised volume data it is possible to calculate a new weighted average selling price. Adjustment of the Douglas-fir volume and price data in this way increased the average selling price for 1977 from $\$ 28.82$ per cubic

Table 2. Comparison of Douglas-fir timber quality on timber sales in the Quadra P.S.Y.U. and the Mt. Baker/Snoqualmie National Forest by log grade1 1977.

Log Grades:

$\begin{array}{lll}\text { No. } 1 & \text { No. } 2 & \text { No. } 3\end{array}$

\section{Region} (Percentage distribution by Volume)

\begin{tabular}{llll}
\hline Quadra P.S.Y.U. & 2 & 34 & 64 \\
$\begin{array}{l}\text { Mt. Baker/Snoqualmie } \\
\text { National Forest }\end{array}$ & 2 & 79 & 19
\end{tabular}

1. Log grades are difficult to compare since official grading rules differ markedly between the two jurisdictions. The grades shown in this table are loosely based on the British Columbia Forest Service statutory grading rules:

No. 1 includes higher quality peeler grades (Nos. 1 \& 2) and No. 1 sawlogs.

No. 2 includes all other peeler grades and No. 2 sawlogs.

No. 3 includes No. 3 sawlogs and lower. 
metre to $\$ 36.98$ per cubic metre and appraised stumpage from $\$ 0.17$ per cubic metre to $\$ 7.13$ per cubic metre. Thus, even when timber quality on the two areas is assumed to be identical, the appraised value for Douglas-fir on the Quadra P.S.Y.U. is still only $38 \%$ of its appraised value on the Mt. Baker/Snoqualmie National Forest.

It has been suggested (C.O.F.I., 1973) that opportunities for marketing timber products are better in the western United States than in British Columbia. However, to a large extent the forest products industries of British Columbia and the Pacific Northwest serve and compete in the same United States' markets for lumber, pulp and newsprint. Coastal British Columbia serves off-shore markets for forest products to a much greater extent than Washington and Oregon, but such market diversification might be considered to be an advantage enjoyed by Canadian producers.

High tariff barriers preclude the export of plywood from British Columbia to the United States. Therefore, most of the plywood produced in both British Columbia and the Pacific Northwest is sold domestically. The larger domestic plywood market in the United States gives plywood producers in Washington and Oregon a definite advantage over the industry in British Columbia. Greater market opportunities are available, the industry is larger and individual firms can achieve economies of scale in production which are unavailable to their British Columbia counterparts. In addition, Douglas-fir, the foremost plywood species, is more readily available in the Pacific Northwest and there is a higher proportion of peelable logs in the harvest. As a result, the forest product mix in the Pacific Northwest has a higher proportion of plywood than in British Columbia, which tends to increase its average value per unit volume.

The forest products industry in Washington and Oregon is closer to the major and burgeoning population centres of the western and southwestern United States and enjoys an advantage in those markets resulting from lower rail and truck transportation costs. However, to the major lumber markets of the midwest, freight rates from Washington, Oregon and British Columbia are comparable and British Columbia producers, because of the United States Merchant Marine (Jones) Act, enjoy a distinct advantage in the United States' eastern seaboard market.

Considerable opportunities exist for firms in the Pacific Northwest to export logs, whereas in British Columbia federal and provincial restrictions effectively preclude log exports (Pearse, 1976). Export log prices are considerably higher, for many species and grades, than domestic prices (Davis, 1977) and it has been suggested (C.O.F.I., 1973) that exports increase average log values and, therefore, the prices firms are willing to bid on public timber in the Pacific Northwest. However, restrictions on log exports from Federal lands in the Western United States have existed since 1969 and, since 1974, there has been a virtual ban on such exports. In addition, regulations exist to discourage the substitution of public timber for private timber which is exported (Lindell, 1978). The state of Oregon has also had regulations since 1963 which effectively ban the export of logs from state managed lands. Washington state has no export restrictions and, as a result, stumpages for state managed timber, particularly in western Washington, are considerably higher than for National Forest timber sales.

Since 1977, the value of the Canadian dollar has fallen considerably vis-à-vis the United States dollar and other leading world currencies. Most of British Columbia's forest products exports are quoted in United States dollars, therefore, a fall in the Canadian dollar relative to the United States dollar improves the industry's competitive position and increases its revenues. Since the industry in Washington and Oregon sells most of its output in the domestic market, exchange considerations have little influence on its sales and profits.

The evidence presented thus far suggests that the differences in appraised stumpages between British Columbia and the Pacific Northwest are only partially explainable in terms of differences in timber quality and market opportunities between the two regions. Another possible explanation, worthy of consideration, is that due to imperfections in the Vancouver Log Market, log prices used for stumpage appraisal purposes in coastal British Columbia do not reflect full timber values. In 1974, the Task Force on Crown Timber Disposal in British Columbia investigated the Vancouver Log Market in some detail and concluded that the structure of the market "is not sufficiently competitive to yield prices that can be depended upon to reflect the full value of timber harvested". Studies prepared for the Task Force indicated that Vancouver Log Market prices "frequently diverge significantly from the values that would be implied by the prices of the products made from them".

While imperfections in the Vancouver Log market may help to explain differences between appraised stumpage values in coastal British Columbia and the Pacific Northwest, the Interior situation is entirely different. In the Interior of British Columbia, as in Washington and Oregon, stumpage appraisals are based upon end product values.

\section{Conclusion}

Stumpages for Crown timber in British Columbia are considerably lower than for public timber in the United States Pacific Northwest, and these price differences are increasing annually. There is little doubt that the principle reason for higher stumpages in the Pacific Northwest is that all public agencies, both state and federal, involved in timber production, encourage competitive bidding for standing timber whereas in British Columbia competitive sales for public timber have been virtually eliminated. Other reasons, of lesser importance, include tax considerations on the part of bidding firms in the Pacific Northwest with private timber holdings, the higher average quality of the timber resource in the Pacific Northwest compared to British Columbia and the fact that forest products companies in Washington and Oregon face better market opportunities, particularly with respect to plywood, than their counterparts in British Columbia.

There is good reason to believe that if public timber in British Columbia was sold competitively, stumpages, in many cases, would be bid well above their appraised level and Crown revenues would be substantially increased, particularly in those regions of the Province where accessible, high quality stands of timber are in short supply. One would also expect the real price of standing timber to show an upward trend over time, reflecting its increasing relative scarcity.

In the Pacific Northwest, as in British Columbia, public agencies appraise the value of standing timber before it is offered for sale. The appraisal method used by the United States Forest Service is similar, in many respects, to the method used by the British Columbia Forest Service. It has been demonstrated in this paper that appraised stumpages for the British Columbia Coast are considerably lower than for western Washington. These differences cannot be explained in terms of cost differentials between the two regions and are only partially explained by differences in timber quality. A possible additional explanation is that due to imperfections in the Vancouver Log market, log prices used for stumpage appraisal purposes in coastal British Columbia consistently fail to reflect full timber values, whereas the United States Forest Service uses end product values (lumber, veneer and chips) as a basis for stumpage appraisals which are determined in highly competitive markets.

The evidence presented in this paper suggests that appraised stumpages in British Columbia fail to reflect the full value of the Province's timber resource and that, in the absence of competitive markets for stumpaqe, public 
revenues from the production and sale of timber are much lower than they could be. Many questions are left unanswered, however, which should be investigated. For example, does the British Columbia government capture a substantial part of the economic rent arising from the utilization of timber resources in ways other than through direct stumpage payments? If the British Columbia government fails to capture the full value of the Province's timber resources, where is the excess value being distributed, that is, who are the beneficiaries of "low cost" timber? If timber in British Columbia is being sold at less than its full market value, what are implications in terms of industrial efficiency, conservation of the timber resource and incentives for reforestation and more intensive resource management?

\section{References}

British Columbia Forest Service. Annual Reports 1963 to 1978. Queen's Drinter, Victoria, B.C.

Council of Forest Industries of British Columbia. 1973. A Regional Comparison of Stumpage, Taxation and Other Factors in the Forest Industries of British Columbia and the U.S. Pacific Northwest. Price Waterhouse \& Co., Vancouver, B.C. 80 pp \& 79 pp \& Append

Davis, D.K. 1977. Log Export Restrictions in British Columbia: An Economic Examination. M.Sc. Thesis, Faculty of Forestry, University of B.C., Vancouver.
Department of Industry, Trade and Commerce. 1977. Analysis of Manufacturing Costs in the North American Forest Products Industries. Prepared by Sandwell Mgmt. Consultants for Forest Products Group, Resource Industries Branch, Dept. of Industry, Trade and Commerce, Ottawa, Ont.

Haynes, R.W., and D.M. Adams. 1979. "Possible Changes in Regional Forest Product Output and Consumption During the Next 50 years". Forest Products Journal 29(10):75-80.

Lindell, Gary, R. 1978. Log Export Restrictions of the Western States and British Columbia. Pacific Northwest Forest \& Range Exp. Station, Tech. Rep. PNW-63. USDA Forest Service, Portland, Oregon.

Pearse, P.H. 1976. Timber Rights and Forest Policy in British Columbia. Report of the Royal Commission on Forest Resources. Two volumes. Queen's Printer, Victoria, B.C. $395+$ App.

Province of British Columbia. 1980. Five-Year Forest and Range Resource Program. Ministry of Forests, Victoria, B.C.

Reed, F.L.C. \& Associates. 1975. Economic Rent and Stumpage. Brief submitted to the Royal Commission on Forest Resources. Vancouver, B.C.

Task Force on Crown Timber Disposal. 1974. Timber Appraisal: Policies and Procedures for Evaluating Crown Timber in British Columbia. B.C. Forest Service, Victoria, B.C.

United States Dept. of Agriculture, Forest Service. Production, Prices, Employment and Trade in Northwest Forest Industries 1963 to 1978 (published quarterly). Pacific Northwest Forest \& Range Exp. Station, Portland, Oregon.

\section{Woodlot Service (1978) Ltd.}

"All Matters Pertaining to Forestry"

GORDON B. YOUNG, B.Sc.F., M.F.

Registered Professional Forester

RESOURCE INVENTORY -

FOREST MANAGEMENT PLANNING

SILVICULTURAL SPECIALISTS

SYSTEM DESIGN AND CONTRACT
EDWARD

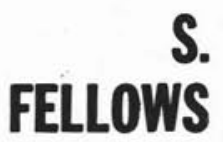

FORESTRY \& FOREST PRODUCTS CONSULTANT

P.O. Box 354, 404 Queen St., MEMBER:

FREDERICTON, N. B.

Registered Professional

Forester (N. B.)

Conadion Institute of Forestry

Forest Products Research Society, Etc.

INDUSTRY DEVELOPMENT - FOREST PRODUCTS ECONOMIC FOREST POLICY \& ADMINISTRATION 